\title{
PENGARUH DUKUNGAN SOSIAL, SELF-ESTEEM DAN SELF-EFFICACY TERHADAP ORIENTASI MASA DEPAN PADA REMAJA AKHIR
}

\author{
Lebis Preska \\ lebizzgh@gmail.com \\ Anggota HIMPSI Provinsi \\ Sumatera Selatan
}

\author{
Zulfa Indira Wahyuni \\ zulfa.indira@uinjkt.ac.id \\ Fakultas Psikologi UIN Syarif \\ Hidayatullah Jakarta
}

\begin{abstract}
This study was conducted to determine the influence of social support, self-esteem and self efficacy to future orientation in adolescence. The subject in this research were 200 adolescence were taken by non probability sampling and purvosive technique. CFA (Confirmatory Factor Analysis) was used to test the validity of instrument and Multiple Regression Analysis was used to test the research hypothesis. The result showed that there is an effect of social support, self-esteem and self efficacy to future orientation in adolescence. Minor hypothesis test result indicated that emotional support, self esteem and self-efficacy have a significant effect on future orientation. The result also showed the proportion of the variance of future orientation described by all independent variables was $29.7 \%$, while $70.3 \%$ was influenced by other variables outside of this research.
\end{abstract}

Keyword: social support, self-esteem, self-efficacy, future orientation, adolescence.

\section{Abstrak}

Penelitian ini dilakukan untuk mengetahui pengaruh dukungan sosial, self esteem dan self efficacy terhadap orientasi masa depan pada remaja akhir. Subjek pada penelitian ini berjumlah 200 siswa kelas XII SMA di Jakarta yang diambil dengan metode non probability sampling, yaitu teknik purposive sampling. CFA (Confirmatory Factor Analysis) digunakan untuk menguji validitas alat ukur dan Multiple Regression Analysis digunakan untuk menguji hipotesis penelitian. Hasil penelitian menunjukkan bahwa ada pengaruh secara bersama-sama dari dukungan sosial, self esteem dan self efficacy terhadap orientasi masa depan pada remaja akhir. Hasil uji hipotesis minor menunjukkan bahwa dukungan emosional, self esteem dan self efficacy memiliki pengaruh yang signifikan terhadap orientasi masa depan. Hasil penelitian juga menunjukkan proporsi varians dari orientasi masa depan yang dijelaskan oleh seluruh variabel independen adalah $29.7 \%$, sedangkan $70.3 \%$ sisanya dipengaruhi oleh variabel lain diluar penelitian ini.

Kata kunci: dukungan sosial, self-esteem, self-efficacy, orientasi masa depan, remaja.

\footnotetext{
Diterima: 14 Januari 2017 Direvisi: 17 Februari_ Disetujui : 19 Maret
} 


\section{PENDAHULUAN}

Ciri utama sebuah pemikiran ataupun tindakan manusia adalah orientasi terhadap kejadian dan hasil di masa depan. Orientasi masa depan merupakan kemampuan seorang individu untuk merencanakan masa depan yang merupakan salah satu dasar dari pemikiran manusia. Setiap orang memiliki tujuan hidup di masa depan agar dapat membuat langkah-langkah untuk mencapai tujuan tersebut. Tujuan hidup di masa depan tidak dapat tercapai ataupun terealisasikan tanpa sebuah pemahaman yang cukup tentang masa depan itu sendiri. Sehingga hal tersebut penting untuk dipersiapkan sebaik mungkin dan juga merupakan hal yang penting bagi setiap orang untuk memahami orientasi masa depan dari dirinya (Putra, 2014).

Seiring berjalannya usia, remaja akan semakin tertarik pada tugas-tugas perkembangannya, seperti pekerjaan masa mendatang, pendidikan, dan keluarga masa depan mereka (Nurmi, Poole, \& Kalakoski, 1994). Hal tersebut berkaitan dengan usia remaja 14 - 18 tahun mereka harus sudah merencanakan karir pekerjaan, pendidikan dan juga keluarga yang akan dipilih sebagai penunjang kesuksesan di masa depan saat dewasa. Tujuan masa depan tersebut menyangkut orientasi masa depan individu terkait pemikiran, perencanaan, motivasi, dan perasaan remaja terhadap masa depannya (McCabe \& Barnett, 2000).

Melihat urgensi dari tujuan masa depan maka peneliti menganggap perlu untuk membahas dan meneliti hal tersebut agar menjadi acuan bagi seluruh masyarakat, khususnya bagi orang tua dalam mengawasi dan mendampingi proses perkembangan dalam kelanjutan bidang pendidikan pada remaja akhir. Maka dari itu, peneliti tertarik untuk melakukan penelitian dengan judul "Pengaruh Dukungan Sosial, Self-Esteem, dan Self-Efficacy terhadap Orientasi Masa Depan pada Remaja Akhir".

\section{KAJIAN TEORI}

\section{Orientasi Masa Depan}

Orientasi masa depan merupakan kemampuan seorang individu untuk merencanakan masa depan yang merupakan salah satu dasar dari pemikiran seorang manusia. Selain itu orientasi masa depan ini menggambarkan bagaimana seorang individu memandang dirinya sendiri di masa mendatang, gambaran tersebut membantu individu dalam menempatkan dan mengarahkan dirinya untuk mencapai apa yang ingin diraihnya. (Nurmi, 1991). Menurut Nurmi, orientasi masa depan adalah suatu konsep multidimensi yang digambarkan sebagai satu kesatuan dari tiga proses psikologis utama sebagai dimensinya, yaitu motivasi, perencanaan, dan evaluasi.

Menurut Nurmi et. al (1994), masa remaja seseorang akan dihadapkan dengan berbagai persoalan hidup terkait dengan tujuan di masa depan seperti pekerjaan, pendidikan ataupun pernikahan dan keluarga. Lalu Santrock (2007) juga menemukan bahwa masa remaja dianggap sebagai masa yang sulit secara emosional. Didukung dengan hasil Survei Kesehatan Reproduksi Remaja (SKKR) 2012 yang menginformasikan bahwa kehidupan remaja di masa mendatang, diprediksi akan menghadapi masalah krusial. Hal itu ditandai 
dengan perkembangan remaja yang akhir-akhir ini sudah mengarah ke perilaku beresiko (Sindotrijaya.com, 2014).

Menteri Pendidikan Nasional Indonesia ke-25, Bambang Sudibyo, mengatakan bahwa "Investasi yang terbaik adalah dalam bidang pendidikan, hanya dengan itu akan terjadi perubahan nasib masyarakat" (Balaitekkomdik, 2009). Sejalan dengan kata dari Menteri Pendidikan Nasional Indonesia ke-25, maka hendaknya setiap orang dapat melanjutkan pendidikannya ke jenjang yang lebih tinggi. Dalam hal ini, peralihan dari bangku sekolah menuju bangku kuliah perlu diperhatikan oleh setiap orang. Remaja siswa kelas XII sudah seharusnya memperhatikan terkait motivasi, perencanaan dan evaluasi mereka dalam menentukan pilihan untuk melanjutkan kuliah dimana dan mengambil jurusan yang sesuai dengan keinginannya.

Namun, hal tersebut masih menjadi sebuah masalah bagi seorang remaja di Indonesia karena masih banyak sebagian besar dari mereka yang tidak memiliki orientasi terhadap masa depan yang jelas di bidang pendidikan dan kesulitan dalam memilih jurusan saat akan masuk kuliah. Hal ini didukung dari hasil studi pendahuluan yang dilakukan oleh peneliti kepada 30 siswa SMA kelas 12 Sekolah X di Tangerang Selatan dan 30 mahasiswa universitas X di Tangerang Selatan yang menunjukkan bahwa sebanyak 19 (63\%) siswa SMA masih kebingungan dalam memilih jurusan dan 16 mahasiswa (53\%) mengaku bahwa mengalami kesulitan dan sempat putus asa karena merasa telah memilih jurusan yang salah. Sehingga dapat dilihat secara umum bahwa lebih dari 50\% siswa ataupun mahasiswa remaja akhir mengalami kebingungan dalam menetukan pendidikan masa depannya.

Tentu saja dengan fenomena tersebut orientasi masa depan di bidang pendidikan memang sudah menjadi hal penting bagi kalangan remaja akhir, karena mereka memiliki hubungan erat terhadap tugas perkembangan di masa dewasa awal. Salah satu fakta lain yaitu dalam penelitian Santrock (2004) pada mahasiswa strata satu di Amerika Serikat yang menunjukkan bahwa hampir setengah dari calon mahasiswa perguruan tinggi merasa kebingungan dalam memilih perguruan tinggi yang akan dituju karena tidak ada dasar yang jelas untuk membuat keputusan, sehingga banyak siswa SLTA memilih perguruan tinggi dengan menutup mata. Lalu ketika mereka masuk kuliah, mereka memutuskan untuk pindah tempat kuliah karena merasa tidak puas dengan pilihannya. Pada akhirnya, kondisi ini berpengaruh pada produktivitas mereka dibangku kuliah dan dapat menambah angka pengangguran (Santrock, 2004).

Secara garis besar, ada dua faktor yang dapat mempengaruhi perkembangan orientasi masa depan. Kedua faktor itu adalah faktor individu (person-related factor) dan faktor konteks sosial (social context-related factor) (Nurmi, 1991). Salah satu aspek konsep diri yang mempengaruhi orientasi masa depan adalah diri ideal. Diri ideal ini memberikan standar perilaku dan berpengaruh dalam pemilihan tujuan individu dan dapat berfungsi sebagai motivasi dalam mencapai tujuan jangka panjang (Nurmi, 1989).

Aspek lain dari konsep diri yang mempengaruhi orientasi masa depan adalah self-esteem. Beberapa studi menunjukkan bahwa individu dengan self-esteem yang 
tinggi akan lebih memikirkan masa depannya secara internal daripada individu dengan self-esteem rendah (Nurmi, 1989).

Kemudian faktor individu yang mempengaruhi orientasi masa depan selanjutnya adalah kematangan kognitif. Penelitian mengenai hubungan kematangan kognitif dengan orientasi masa depan memberikan hasil yang berbeda-beda. Beberapa ahli menjelaskan perkembangan kognitif dapat mempengaruhi rencana masa depan remaja. Hal ini karena remaja berada dalam tahap formal operation. Dalam tahap ini remaja mampu membuat hipotesis yang bertentangan dengan kenyataan dan mampu menggali berbagai kemungkinan (Elkind, dalam Nurmi, 1991). Selain itu, dalam tahap ini kemampuan metakognisi remaja berkembang (Keating dalam Nurmi, 1991). Kemampuan ini sangat memungkinkan remaja untuk memikirkan kemungkinan yang akan terjadi di masa depan, menemukan masalah dalam pencapaian tujuan dan memberikan solusinya. Kematangan kognitif sangat erat kaitannya dengan kemampuan intelektual sehingga menjadi salah satu faktor individu yang mempengaruhi orientasi masa depan.

Setelah faktor individu, terdapat pula faktor konteks sosial yang mempengaruhi orientasi masa depan, yaitu status sosial ekonomi dan hubungan dengan orangtua. Beberapa penelitian menunjukkan bahwa tingkat sosial ekonomi mempengaruhi orientasi masa depan. Seperti penelitian yang dilakukan oleh Lamm et al (dalam Nurmi, 1991) menemukan bahwa remaja yang berasal dari sosial ekonomi menengah menyatakan lebih banyak harapan yang berkaitan dengan kehidupan sosial di masa depan dibandingkan dengan remaja dari sosial ekonomi rendah.

Kemudian keluarga merupakan model bagi remaja dan merupakan wadah yang tepat dalam menyelesaikan tugas perkembangan yang sedang dihadapi atau yang akan dihadapi. Semakin positif hubungan orang tua dengan remaja maka akan semakin mendorong remaja memikirkan masa depan. Asumsi umum dalam teori pembelajaran sosial menyatakan bahwa orang tua yang memberikan penghargaan positif terhadap anak-anaknya dan konsisten dalam praktek sosialisasi mengarahkan anaknya memiliki harapan yang positif mengenai dunia luar, mempercayai orang lain, yakin akan kemampuan sendiri dan optimis (Nurmi, 1991). Selain hubungan dengan orangtua, kelompok teman sebaya juga memungkinkan individu untuk mendapatkan insentif mengenai tugas kehidupan, saling membandingkan perilaku dan akhirnya mempengaruhi bagaimana individu berpikir mengenai masa depan (Nurmi, 1991).

\section{Dukungan Sosial}

Melihat dari faktor-faktor yang mempengaruhi orientasi masa depan di atas, dukungan sosial terutama dari orang tua merupakan faktor penting yang mempengaruhi orientasi pendidikan di masa depan pada remaja dalam mencapai tujuan akademik. Keluarga dan juga hubungan orang tua dengan anak yang sudah pada tahapan remaja merupakan konteks sosial yang penting terhadap perkembangan remaja. Meskipun teman sebaya berpengaruh pada masa remaja namun tetap saja peran orang tua menjadi sumber penting dalam menentukan 
setiap keputusan terhadap tujuan yang akan dipilih untuk kehidupan di masa depannya.

Adapun definisi dukungan sosial menurut Sarafino (1994) yaitu bentuk penerimaan dari seseorang atau sekelompok orang terhadap individu yang menimbulkan persepsi dalam dirinya bahwa ia disayangi, diperhatikan, dihargai dan ditolong. Dukungan sosial merupakan bentuk pemberian informasi serta merasa dirinya dicintai dan diperhatikan, terhormat, dan dihargai, serta merupakan bagian dari jaringan komunikasi dan kewajiban timbal balik dari orangtua, kekasih/ kerabat, teman, jaringan lingkungan sosial serta dalam lingkungan masyarakat. Sarafino (1997), mengatakan bahwa dukungan social memiliki lima aspek, yaitu : dukungan emosional (emotional support), dukungan penghargaan (esteem support), dukungan instrumental (instrumental support), dukungan informasi (information support), dukungan jaringan sosial (network support).

Penelitian McCabe dan Barnett (2000) menemukan bahwa dukungan sosial dari orang tua mempengaruhi orientasi masa depan pada remaja. Remaja yang memandang adanya dukungan dan keterbukaan dari orang tua akan mendapatkan orientasi masa depan yang lebih positif dari pada remaja yang kurang mendapatkan dukungan dari orang tuanya.

\section{Self-Esteem}

Selain dukungan sosial, faktor selfesteem dari individu turut berpengaruh terhadap orientasi pendidikan masa depan remaja. Coopersmith (1990) mengungkapkan bahwa self-esteem adalah evaluasi yang dibentuk berdasarkan kebiasaan individu memandang dirinya terutama mengenai sikap menerima atau menolak dan indikasi besarnya kepercayaan individu terhadap kemampuannya, keberartiannya, kesuksesannya, dan keberhargaannya. Menurut Coopersmith terdapat lima aspek self esteem, yaitu : keberhasilan, tata nilai, aspirasi, dan pertahanan.

Penelitian yang dilakukan oleh Plante (1997) menunjukkan bahwa self-esteem memiliki pengaruh terhadap orientasi masa depan. Individu dengan self-esteem yang tinggi akan lebih memikirkan orientasi masa depan pendidikannya. Lalu Nurmi (1991) mengatakan bahwa semakin tinggi harga diri (self-esteem) remaja maka semakin tinggi orientasi pendidikan masa depan remaja.

\section{Self-Efficacy}

Selanjutnya banyak penelitian yang berfokus pada konsep self-efficacy pada ranah akademik remaja. Self-efficacy berkorelasi dengan orientasi masa depan remaja (Beal, 2011). Menurut Bosscher \& Smit (1998) self-efficacy adalah keyakinan seseorang dalam memahami kemampuannya untuk mengatur dan melaksanakan perilaku tertentu yang diperlukan untuk menghasilkan pencapaian dari tugas yang dimiliki. Bandura (1995) mengemukakan bahwa self-efficacy adalah keyakinan seseorang terhadap kemampuannya untuk menyusun tindakan yang dibutuhkan dalam menyelesaikan tugas-tugas khusus yang dihadapi sehingga keyakinan tersebut mempengaruhi cara berpikir, perasaan, motivasi terhadap diri 
dan tindakan yang dilakukan. Bosscher dan Smit (1998) mengungkapkan tiga dimensi dari self-efficacy adalah initiative, effort, dan persistence.

Skinner, Zimmer-Gembeck, \& Connell (1998) mengemukakan bahwa remaja yang memiliki tingkat self-efficacy tinggi, ia memiliki nilai lebih dalam menentukan tujuan mereka secara konkrit, membentuk rencana yang logis, dan merasa tertantang untuk mencapai tujuan. Selain itu, Bandura, Barbarenelli, Caprara, \& Pastorelli (1996) menegaskan bahwa semakin tinggi tingkat self-efficacy maka akan memiliki cita-cita yang lebih tinggi pula dan juga komitmen dalam mencapai citacita tersebut.

\section{METODE PENELITIAN}

\section{Populasi, sampel dan teknik pengambilan sampel}

Penelitian ini menggunakan pendekatan kuantitatif dengan analisis regresi berganda. Dalam penelitian ini yang dijadikan populasi adalah siswa kelas 12 di Sekolah Provinsi DKI Jakarta. Sampel dalam penelitian ini berjumlah 200 orang.

Teknik pengambilan sampel dalam penelitian ini menggunakan teknik nonprobability sampling dimana peluang terpilihnya anggota populasi tidak dapat diketahui. Hal tersebut dikarenakan peneliti tidak memiliki data seluruh anggota populasi, selain itu seluruh anggota populasi tidak memiliki peluang yang sama untuk menjadi sampel. Cara pengambilan sampel menggunakan purposive sampling, dimana kriteria orang yang akan dijadikan sampel ditentukan oleh peneliti, dalam hal ini merupakan remaja akhir yang berstatus sekolah kelas 12 di Provinsi DKI Jakarta, serta snowball sampling, dimana jumlah sampel bergulir atau meningkat dari satu orang kemudian menyebar ke beberapa orang. Selain menyebarkan kuesioner secara langsung, peneliti menggunakan google forms untuk menyebar kuesioner kepada partisipan kemudian partisipan tersebut menyebarkannya kepada teman atau kenalannya yang memenuhi kriteria untuk menjadi sampel kemudian mengisi sampel tersebut secara online.

\section{Instrumen penelitian}

Alat ukur untuk variable orientasi masa depan yang digunakan pada penelitian ini adalah alat ukur modifikasi dari Future Orientation Questionnaire oleh Nurmi (1989), yang berisi 32 item untuk mengukur aspek motivasi, perencanaan, dan evaluasi seseorang dalam menghadapi masa depan.

Untuk variable dukungan sosial, peneliti menggunakan adaptasi dari skala dukungan sosial oleh Sarafino (1997), digunakan untuk mengungkapkan dukungan sosial yang bersumber pada dukungan orang tua pada subjek penelitian yang terdiri dari 28 item yang diterjemahkan ke dalam Bahasa Indonesia. Kemudian variabel self-esteem dalam penelitian ini diukur dengan menggunakan skala The School Short-form Coopersmith Self-esteem Inventory. Skala erupakan pengembangan dari self-esteem coopersmith inventory yang dilakukan oleh Hills, Francis, dan Jennings (2011) dan dirancang khusus untuk anak-anak sekolah. Item kuesioner ini terdiri dari 25 item yang mengukur keberhasilan, nilai-nilai, aspirasi, dan pertahanan. 
Lalu untuk variable self-efficacy dalam penelitian ini diukur dengan General Self-Efficacy Scale (GSES-12) oleh Bosscher \& Smit (1998), dikarenakan semua item di dalam General Self-Efficacy Scale (GSES-12) itu telah mengalami revisi dari General Self-Efficacy Scale sebelumnya. Sehingga 5 dari 17 item telah dikeluarkan dari GSES, karena kata-kata yang ambigu dan berkorelasi rendah. Selain revisi yang telah dilakukan, peneliti juga melakukan penambahan jumlah item sebanyak tiga item. Hal ini dilakukan untuk mengantisipasi apabila pada nantinya terdapat item yang tidak valid sehingga harus didrop, jumlah item akan tetap mencukupi.

Semua alat ukur diuji validitas dengan CFA (Confirmatory Factor Analysis) dengan menggunakan 3 kriteria untuk item yang valid yaitu muatan faktor tidak boleh negative, $t$-value $>1.96$, dan korelasi residual tidak lebih dari tiga.

\section{HASIL PENELITIAN}

Pada penelitian ini diperoleh $\mathrm{R}^{2}$ sebesar 0.297 atau $29.7 \%$. Artinya proporsi varians dari orientasi masa depan yang dijelaskan oleh semua independent variable dalam penelitian ini adalah sebesar $29.7 \%$, sedangkan $70.3 \%$ lainnya dipengaruhi oleh variabel lain diluar penelitian ini. Berikut tabel R Square :

Tabel 1

Model Summary

\begin{tabular}{ccccc}
\hline Model & R & R Square & Adjusted R Square & Std. Error of the Estimate \\
\hline 1 & $.545^{\mathrm{a}}$ & .297 & .271 & 7.16646 \\
\hline
\end{tabular}

a. Predictors: (Constant), Dukemo, Dukpeng, Dukins, Dukinfor, Dukjejar, Ses, Sef.

Tabel 2

Koefisien Regresi

\begin{tabular}{llllll}
\hline Model & \multicolumn{5}{l}{ Unstandardized Coefficients } \\
& $\mathrm{B}$ & $\begin{array}{l}\text { Standardized } \\
\text { Coefficients } \\
\text { Beta }\end{array}$ & $\mathrm{t}$ & $\mathrm{S}$ Sig. \\
\hline (Constant) & 6.278 & 6.539 & & .960 & .338 \\
Dukemo & .154 & .079 & .136 & 1.941 & .054 \\
Dukpeng & .030 & .066 & .027 & .450 & .654 \\
Dukins & .018 & .063 & .018 & .281 & .779 \\
Dukinfor & .049 & .077 & .045 & .637 & .525 \\
Dukjejar & .045 & .055 & .053 & .816 & .415 \\
Ses & .134 & .067 & .127 & 1.999 & .047 \\
Sef & .445 & .064 & .437 & 7.006 & .000 \\
\hline
\end{tabular}

a. Dependent Variable: $O M D$

Tabel 2 menunjukkan bahwa terdapat empat variabel yang berpengaruh namun tidak secara signifikan terhadap orientasi masa depan di penelitian ini, yaitu dukungan penghargaan, dukungan instrumental, dukungan informasi, dan dukungan jaringan sosial. Variabel lainnya yaitu dukungan emosional, self-esteem, 
dan self-efficacy mempengaruhi orientasi masa depan secara signifikan. Untuk mengetahui signifikan atau tidaknya koefisien regresi yang dihasilkan, peneliti melihat nilai signifikansi pada kolom ketiga dari kiri. Jika sig $<0.05$, maka koefisien regresi yang dihasilkan signifikan pengaruhnya terhadap orientasi masa depan dan sebaliknya.

\section{KESIMPULAN DAN SARAN}

\section{Kesimpulan}

Berdasarkan hasil analisis data penelitian maka dapat disimpulkan bahwa ada pengaruh yang signifikan dari dukungan emosional, dukungan penghargaan, dukungan instrumental, dukungan informasional, dan dukungan jejaring sosial serta self esteem dan self efficacy terhadap orientasi masa depan. Berdasarkan hasil proporsi varians keseluruhan, orientasi masa depan dipengaruhi oleh dukungan emosional, dukungan penghargaan, dukungan instrumental, dukungan informasional, dan dukungan jejaring sosial serta self esteem dan self efficacy yaitu sebesar 29.7\%. Sedangkan dalam hasil dari uji hipotesis yang telah dilakukan, terdapat dua variabel yang signifikan yaitu self esteem dan self efficacy, maka ada pengaruh yang signifikan dari dukungan self esteem dan self efficacy terhadap orientasi masa depan.

\section{Diskusi}

Hasil penelitian menunjukkan bahwa self esteem dan self efficacy memberi pengaruh signifikan terhadap orientasi masa depan. Variabel dukungan emosional memiliki pengaruh signifikan terhadap orientasi masa depan. Temuan ini sejalan dengan Hasil penelitian Rarasati et al. (2012) menyatakan bahwa orang tua dan lingkungan di sekitarnya adalah yang paling penting dalam lingkungan mereka yang dapat sangat mendukung pencapaian remaja pada masa depan. Dukungan emosional merupakan dukungan yang diberikan orang tua terhadap anak dalam bentuk empati, perhatian, kasih sayang, dan kepedulian sehingga menimbulkan kelekatan emosional yang baik. Hal ini menjadikan dukungan emosional bisa signifikan.

Variabel self esteem memiliki pengaruh signifikan dengan arah positif terhadap orientasi masa depan. Dari arah hubungan tersebut dapat diartikan jika self esteem individu itu tinggi maka orientasi masa depan akan tinggi ataupun sebaliknya. Temuan ini searah dengan penelitian Plante (1997) menunjukkan bahwa selfesteem memiliki pengaruh terhadap orientasi masa depan. Individu dengan selfesteem yang tinggi akan lebih memikirkan orientasi masa depan pendidikannya.

Variabel self efficacy memiliki pengaruh signifikan dengan arah positif terhadap orientasi masa depan. Dari arah hubungan tersebut dapat diartikan jika self efficacy individu itu tinggi maka orientasi masa depan akan tinggi ataupun sebaliknya. Temuan ini searah dalam Skinner, Zimmer-Gembeck, \& Connell (1998) mengemukakan bahwa remaja yang memiliki tingkat self-efficacy tinggi, ia memiliki nilai lebih dalam menentukan tujuan mereka secara konkrit, membentuk rencana yang logis, dan merasa tertantang untuk mencapai tujuan. 
Selain itu, Bandura, Barbarenelli, Caprara, \& Pastorelli (1996) menegaskan bahwa semakin tinggi tingkat self-efficacy maka akan memiliki cita-cita yang lebih tinggi pula dan juga komitmen dalam mencapai cita-cita tersebut.

Sedangkan, variabel lain tidak memenuhi signifikan adalah dukungan penghargaan, dukungan instrumental, dukungan informasional, dan dukungan jejaring sosial.

Variabel dukungan penghargaan tidak memiliki pengaruh signifikan dengan orientasi masa depan. Sarafino (2004) menyebutkan dukungan ini mengacu kepada pemberian semangat dan perbandingan yang positif terhadap individu lain. Dalam penelitian ini, peneliti melihat bahwa responden dalam lingkungan dan kurikulum belajar siswa kelas XII sangat berkompetisi, sehingga dukungan penghargaan tidak signifikan.

Variabel dukungan instrumental tidak memiliki pengaruh signifikan terhadap orientasi masa depan. Menurut Health Psychology, Sarafino (2004) mengatakan bahwa dukungan instrumental merupakan pemberian pertolongan berupa barang atau jasa disaat dibutuhkan. Disini jelas respoden masih terikat erat dengan dorongan oleh orang tua maupun wali, dalam hal ini materil. Oleh karena itu dukungan instrumental berupa dukungan jasa tidak berpengaruh secara signifikan.

Variabel dukungan informasional tidak memiliki pengaruh signifikan terhadap orientasi masa depan. Sarafino (2004) mengatakan bahwa dukungan informasional mengacu pada pemberian saran atau umpan balik yang dapat menolong individu untuk dapat mengenali dan mengatasi masalah dengan lebih mudah. Sudah canggihnya teknologi yang telah digunakan ditiap-tiap sekolah dan waktu yang lebih terbuka dari pada siswa dibawah kelas XII dalam menggunakan teknologi ini, sehingga responden akan lebih mendapati banyak informasi, bahkan dari pimpinan mereka. Oleh karena itu dukungan informasional tidak berpengaruh secara signifikan.

Variabel dukungan jejaring sosial tidak memiliki pengaruh signifikan terhadap orientasi masa depan. Temuan ini sama halnya seperti yang telah dipaparkan pada dukungan penghargaan, sehingga variabel ini tidak signifikan.

\section{Saran}

Dalam penelitian ini, peneliti menyadari bahwa masih terdapat banyak kekurangan. Untuk itu, peneliti memberikan beberapa saran sebagai bahan pertimbangan untuk dapat melengkapi penelitian selanjutnya, baik berupa saran teoritis maupun saran praktis.

\section{Saran Teoritis}

1. Dalam penelitian ini besar pengaruh independent variable terhadap dependent variable sebesar $29.7 \%$ artinya masih ada $70.3 \%$ variabel lain yang memengaruhi orientasi masa depan. Diharapkan penelitian selanjutnya dapat memasukkan variabel-varibel lainnya yang memengaruhi orientasi masa depan seperti keterlibatan locus of control, kepribadian, character strength dan faktor demografis dan pengaruh masyarakat dan budaya. 
2. Dari hasil penelitian ini, penelitian selanjutnya diharapkan dapat membandingkan sampel tidak hanya dari karakteristik orientasi masa depan pada siswa SMA kelas XII tetapi juga orientasi masa depan pada para individu yang telah lulus SMA bahkan yang telah bekerja.

\section{Saran Praktis}

Setelah di dapatkan hasil penelitian menunjukkan dukungan social, selfesteem dan self efficacy dapat memberikan pengaruh yang signifikan terhadap orientasi masa depan pada siswa SMA kelas XII sebesar 29.7\%, dimana variabel yang signifikan antara lain dukungan emosional, self esteem dan self efficacy.

Variabel dukungan emosional menjelaskan siswa akan dapat mengikuti kurikulum di sekolah dan mengerjakan dengan baik tugas-tugas dan ujian dari sekolah bilamana memiliki teman akrab maupun sahabat. Mereka akan memiliki kelekatan emosional yang tinggi dan ini sangat baik. Dukungan dari pihak-pihak sekolah juga yang penting sebagai pengganti peran orang tua selama responden di sekolah.

Variabel self esteem menjelaskan siswa yang mendapatkan peringkat dengan nilai tertinggi akan mendapatkan peluang yang lebih besar dalam mengambil SBMPTN Undangan, karena diurutkan sesuai peringkat/ lebih kurang didahulukan.

Variabel self efficacy menjelaskan bahwa siswa tingginnya self efficacy tinggi juga komitmen siswa dalam mencapai masa depan mereka. Dengan mengikuti bimbel dan kursus-kursus diluar sekolah, maupun private atau non private.

Dalam penjelasan diatas maka sudah selayaknya tiap-tiap sekolah lebih mengembangkan dukungan emosional, self esteem dan self efficacy dari tiap-tiap siswa untuk menciptakan siswa yang memiliki cit-cita tinggi dan masa depan yang cerah.

\section{DAFTAR PUSTAKA}

Alwisol. (2009). Psikologi kepribadian (edisi revisi). Malang: UMM Press. Annunziata, D., Hogue, A., Faw, L., \& Liddle, H. A. (2006). Family functioning and school success of at-risk, inner-city adolescents. Journal of Youth and Adolescence, 35, 105-113.

Bandura, A. (1995). Self-efficacy in changing societies. New York: Cambridge University Press.

Bandura, A., Barbarenelli, C., Caprara, G. V., \& Pastorelli, C. (1996). Multifaceted impact of self-efficacy beliefs on academic functioning. Child Development, 67, 1206-1222.

Bandura, A., Barbaranelli, C., Caprara, G. V., \& Pastorelli, C. (2001). Self-efficacy beliefs as shapers of children's aspirations and career trajectories. Child development, $72(1), 187-206$.

Beal, S. J. (2011). The development of future orientation: Underpinnings and related constructs. Dissertation, University of Nebraska-Lincoln.

Bosscher, R. J., \& Smit, J. H. (1998). Confirmatory factor analysis of the general self-efficacy scale. Behaviour research and therapy, 36(3), 339-343. 
Coopersmith, S. (1981). SEI, Self-Esteem Inventories. Consulting Psychologist Press.

Coopersmith, S. (1990). The antecedents of self-esteem, Consulting Psychologists Press.

Cutrona, C. E. (1990). Stress and social support: In search of optimal matching. Journal of Social and Clinical Psychology, 9, 3-14.

Dunkel-Schetter, C., Folkman, S., \& Lazarus, R. S. (1987). Correlates of social support receipt. Journal of Personality and Social Psychology, 53, 71-80.

Greene, A. L. (1986). Future time perspective in adolescence: The present of things future revisited. Journal of Youth and Adolescence, 15, 99-113.

Gutman, L. M., \& Midgley, C. (2000). The role of protective factors in supporting the academic achievement of poor African American students during the middle school transition. Journal of Youth and Adolescence, $29,223-348$.

Heatherton, T. F., Wyland, C. L., \& Lopez, S. J. (2003). Assessing self-esteem. Positive psychological assessment: A handbook of models and measures, 219-233.

Helmreich, R., \& Stapp, J. (1974). Short forms of the Texas Social Behavior Inventory (TSBI), an objective measure of self-esteem. Bulletin of the Psychonomic Society, 4(5), 473-475.

Hills, P. R., Francis, L. J., \& Jennings, P. (2011). The school short-form Coopersmith self-esteem inventory: Revised and improved. Canadian Journal of School Psychology, 26(1), 62-71.

Hurlock, E. B. (1999). Perkembangan anak jilid 1. Jakarta: Erlangga. Kerpelman, J. L., Shoffner, M. F., \& Ross-Griffin, S. (2002). African American mothers' and daughters' beliefs about possible selves and their strategies for reaching the adolescents' future academic and career goals. Journal of Youth and Adolescence, 31, 289- 302.

Kerpelman, J. L., \& Mosher, L. S. (2004). Rural African American adolescents' future orientation: The importance of self-efficacy, control and responsibility, and identity development. Identity: An International Journal of Theory and Research, 4, 187-208.

Kerpelman, L. J., Eryigit, S., \& Stephens, J. C. (2008). African American adolescents' future education orientation: associations with self-efficacy, ethnic identity, and perceived parental support. Journal Youth Adolescence, 37, 997-1008.

Lamm, H.. Schmidt, R. W., \& Trommsdorff, G. (1976). Sex and social class as determinants of future orientation in adolescent. Journal of Personality and Social Psychology, 34, 317-326.

Larsen, R. J., \& Buss, D. M. (2008). Personality psychology. Jastrebarsko: Naklada Slap, 269-71.

Lent, R. W., Brown, S. D., \& Larkin, K. C. (1984). Relation of selfefficacy expectations to academic achievement and persistence. Journal of Counseling Psychology, 31, 356-362. 
McCabe, K. M., \& Barnett, D. (2000). First comes work, then comes marriage future orientation among African American young adolescents. Journal of Interdisciplinary Journal of Applied, Vol. 49, No. 1.

Minchinton, J. (1993). Maximum self-esteem: The handbook of for reclaiming tour sense of self-worth. Kuala Lumpur: Golden Books Center SDN, BHD.

Mruk, C. J. (2006). Self-esteem research, theory, and practice: Toward a positive psychology of self-esteem. Springer Publishing Company.

Nurmi, J. E. (1989). Planning, motivation, and evaluation in orientation to the future: A latent structure analysis. Scandinavian Journal of Psychology, 30, 64-71.

Nurmi,J. E. (1991). How do adolescents see their future? A review of development of future orientation and planning development review. Development Review, 11, 1-59.

Nurmi, J. E., Pole, M. E., Kalakoski, V. (1994). Age differences in adolescent future-oriented goals, concern, and related temporal extension in different sociocultural contexts. Journal of Youth and Adolescence, Vol. 23, No. 4, $471-487$

Patchin, J. W., \& Hinduja, S. (2010). Cyberbullying and self-esteem. Journal of school health, 80(12), 614-621.

Plante, T. G., \& Boccaccini, M. T. (1997). The Santa Clara strength of religious faith questionnaire. Pastoral Psychology, 45(5), 375-387.

Powell, M. L., Newgent, R. A., \& Lee, S. M. (2006). Group cinematherapy: Using metaphor to enhance adolescent self-esteem. The arts in psychotherapy, 33(3), 247-253.

Pulkkinen, L. \& Ronka, A. (1994). Personal control over development, identity formation, and future orientation as components of life orientation: A development approach. Developmental Psychology, Vol. 30, No. 2, 260271.

Putra, Dwirifqi. (2014). Pengaruh dukung sosial dan self-efficacy terhadap orientasi masa depan pada remaja.

Rasarati, N., Hakim, M. A., Yuniarti, K. W. (2012). Javanese adolescents' future orientation and support for its effort: An indigenous psychological analysis. World Academy of Science, Engineering and Technology, 66, 597-601.

Roid, G. H., \& Fitts, W. H. (1988). Tennessee self-concept scale (TSCS): revised manual. Western Psychological Services.

Rosenberg, M. (1965). Rosenberg self-esteem scale (RSE). Acceptance and commitment therapy. Measures package, 61,52 .

Santrock, J. W. (2003). Educational psychology. New York: McGraw-Hill.

Santrock, J. W. (2007). Perkembangan anak, edisi ketujuh, jilid dua. Jakarta: Erlangga.

Sarafino, E. P. (1997). Health psychology Biopsychosocial Interactions ( $3^{\text {rd }}$ ed). New York: Jhon Wiley \& Sons inc.. 
Sarason, I. G., Levine, H. M., Basham, R. B. (1983). Assessing social support: The social support questionnaire. Journal of Personality and Social Psychology, 44, 127-139.

Saunders, J., Davis, L., Williams, T., \& Williams, J. H. (2004). Gender differences in self-perceptions and academic outcomes: A study of African American high school students. Journal of Youth and Adolescence, 33, 81-91.

Scheier, M. F., Carver, C. S., \& Bridges, M. W. (1994). A re-evaluation of the life orientation test. Journal of Personality and Social Psyhology, 44, 127139.

Seginer, R. (2009). Future orientation: Developmental and ecological perspective. New York: Springer.

Skinner, E. A., Zimmer-Gembeck, M. J., \& Connell, J. P. (1998). Individual differences and the development of perceived control. Monographs of the Society for Research in Child Development, Series 254, 63(2-3), V-220.

Smith, T. E. (1991). Agreement of adolescent educational experience with perceived maternal and paternal educational goals. Youth \& Society, 23, $155-174$.

Smith, A., Schneider, B. H., \& Ruck, M. D. (2005). 'Thinking about makin' it': Black Canadian students' beliefs regarding education and academic achievement. Journal of Youth and Adolescence, 34, 347-359.

Suryadi, Bambang. (2013). Kehidupan remaja hadapi masalah krusial. Diunduh: http://www.sindotrijaya.com/news/detail/4911/kehidupan-remajahadapi-masalah-krusial

Taylor, R. D., \& Lopez, E. I. (2005). Family management practice, school achievement, and problem behavior in African American adolescents: Mediating processes. Applied Developmental Psychology, 26, 39-49.

Trommsdorff, G. (1986). Future time orientation and its relevant for developments as action. Berlin: Spiner, pp. 121-136.

Undang-undang No. 20 Tahun 2003 tentang Sistem Pendidikan Nasional

Wilson, P. M., \& Wilson, J. R. (1992). Environmental influences on adolescent educational aspirations. Youth \& Society, 24, 52-70.

Zhang, J. X., \& Schwarzer, R. (1995). Measuring optimistic self-beliefs: A Chinese adaptation of the General Self-Efficacy Scale. Psychologia: An International Journal of Psychology in the Orientation. 